\title{
Constitutional Court, Judicial Independence, and Efforts to Achieve Qualified Justice
}

\author{
Irfan Nur Rachman
}

Researcher at the Constitutional Court of the Republic of Indonesia; Doctoral Candidate from Faculty of Law, Diponegoro University, Indonesia.

E-mail: irfan_nrachman@yahoo.com

\section{ARTICLE INFO}

Keywords:

Constitutional Court;

Judicial Corruption; Justice;

Quality Judiciary

How to cite:

Rachman, I.N. (2019).

"Constitutional Court,

Judicial Independence, and

Efforts to Achieve Qualified

Justice,"Hasanuddin Law

Review, 5(1): 86-101

DOI:

10.20956/halrev.v5i1.1471

\section{ABSTRACT}

Judicial Corruption is a disgrace to the world of justice and disaster for the justice seeker community. The judiciary is the third branch of state power after the executive and legislature. The judicial function is as a control and a counterweight to both branches of the power so as not to fall into arbitrary acts. In other words, the judiciary basically serves to implement the principle of checks and balances. However, if the justice functioning as a counterweight is actually involved in the vortex of judicial corruption that has plagued the judicial institutions, then what happens is the absence of justice because the judicial institution becomes unqualified and degrades its reputation in the public eye. This will lead to a vote of no confidence in the judiciary as a whole and the community has the potential to seek justice in other ways that may be done in illegal ways. Therefore, it is important to realize quality judiciary by organizing institutional aspects, the process of recruitment of constitutional justices, and producing decisions containing new legal breakthroughs, so that will be realized a qualified judicial institution.

Copyright (C) 2019 HALREV. All rights reserved.

\section{Introduction}

Several months ago, exactly on March 12, 2018, the world of law was again thrown by his 7 (seven) people handed down by judges, clerks, lawyers and private parties by the Indonesia Corruption Eradication Commission (hereinafter abbreviated as, KPK)1. The

\footnotetext{
KPK was formed based on Law Number 30 of 2002 concerning the Corruption Eradication Commission, the Corruption Eradication Commission (KPK) is given the mandate to eradicate corruption in a professional, intensive and sustainable manner. The KPK is an independent state institution that carries out its duties and authority free from any authority. The Corruption Eradication Commission is not to take over the eradication of corruption from existing institutions. Explanation of the law states the role of the KPK as a trigger mechanism, which is intended to encourage or as a stimulus so that corruption eradication assistance by existing institutions becomes more effective and efficient. Available from: https://www.kpk.go.id/id/tentangkpk/sekilas-komisi-pemberantasan-korupsi [Accessed May 2,2019].
} 
coverage of hand-catching (here in after abbreviated as OTT) operations is rife in various news media as well as social media. The judicial apparatus that was caught was from the Tangerang District Court. Sometimes, they often shares with certain parties to take the benefit of the case that being handled in the judiciary. In fact, at the end of 2017, the Chief of Manado High Court, North Sulawesi and a corruption judge (corrupt) judge of Bengkulu were also caught in hand-catching operations. Not long ago, this month back the judicial apparatus in Tangerang netted OTT operation along with unpredictable litigants.

The rise of OTT events by the KPK to the judicial apparatus makes the legal world gloomy in our country. The dignity of the judiciary become cheap goods that are often sold on the black market. Judicial corruption increasingly appears to be systemically infecting the world of justice. Reasonable in 2014, Sebastian Pompe, ${ }^{2}$ published a book entitled, "The Collapse of the Supreme Court Institution". In summary, Pompe reviews institutional failures, and comparative studies of judicial bodies. At the same time, it is an extraordinary history of the Supreme Court and the tremendous effort to seek the causes of its decline toward corruption and dependence, which involuntarily involves the entire civil justice system. Judicial corruption turned out not only to override the Supreme Court, the Constitutional Court had once tripped a case of judicial corruption involving the Chief Justice of the Constitutional Court at the time of handling the dispute over the election results. In early 2017 there was an OTT event against one of the constitutional judges on a judicial review case of a law. Even the employee and the security of the Constitutional Court were handed over to the authorities due to selling copies of the petition to be examined in the hearing. The absence of a mechanism requiring that an application file be immediately downloaded on the Constitutional Court page becomes a legal loophole in this case.

In general, the judicial corruption mode leads to the efforts of the parties to influence judgment. The verdict that should be the crown of a judicial institution, often traded cheaply. Judicial corruption like a potentially decaying cancer of the judicial institution from within. If the judicial institution has been infected with this acute illness, then finally the attitude of distrust to the judicial institution will arise. The implications of a court that loses its dignity culminate in the potential rise of street justice in which people will seek justice based on their own way. This is certainly very dangerous if allowed to drag on.

On the other hand, the role of the Constitutional Court is very strategic in examining, adjudicating and deciding constitutional cases that often position parties from other branches of power in trials, such as the President and the House of Representatives as providers in the examination of laws or political parties in disputes election results is a vulnerable point and prone to intervene on the Constitutional Court. Not to mention the other temptations that are getting stronger and trying to infiltrate the Constitutional Court in order to influence the decision. Many parties are finally aware of the strategic position of the Constitutional Court. Therefore, efforts to maintain the courts of justice need to be done while mapping and closing the potential of open gaps of corruption. This paper will discuss several problems, namely about a brief portrait of the independence of the judiciary in Indonesia. Second, the discussion will be approved when waiting to be approved by the Constitutional Court as a modern court and can be trusted through a professional judicial manager. Third, the discussion will emphasize

2 Sebastian Pompe. (2012). Runtuhnya Institusi Mahkamah Agung. Jakarta: Lembaga Kajian dan Advokasi untuk Independensi Peradilan,p.12-13. 
the approval of an independent and independent court of ethics council. Fourth, the discussion will discuss the pattern of recruitment of judges who also influence the level of independence of judges. Fifth, legal issues that are discussed are related to decisions that have become historic decisions and are the result of quality judicial implementation.

\section{A Brief Portrait of Judicial Independence}

Judicial independence is closely related to the idea of conflict resolution by third parties. In other words, a person trusted to settle a controversy after considering the facts and their connection with the relevant law or idea which affirms that the dispute must be settled by a judge who has no connection with the Petitioner and has no interest in a case. ${ }^{3}$ According to Becker, ${ }^{4}$ judicial independence is:

a. The degree to which judges...decide [cases] consistent with...their interpretation of law;

b. In opposition to what others, who are perceived to have political or judicial power, think about desire in like matters;

c. Particularly when a decision averse to the beliefs or desires of those with political or judicial power may bring some retribution on the judges personally or on the power of the court.

Meanwhile, according to Keith Rosenn, judicial independence as the degree to which judges actually decide cases in accordance with their own determinations of the evidence, the law and justice, free from corcion, blandishments, interference, or threats from governmental authorities or private citizens. ${ }^{5}$ Briefly, Joel G. Verner's brief definition of judicial independence as," the ability to decide cases on the basis of established law and the merits of case, without substantial interference from other political or governmental agents. ${ }^{6}$

Two thirds of the world's current written constitutions contain some form of explicit protection for the independence of the judiciary, and the proportion of constitutional documents that contain such protections has been rising over time. ${ }^{7}$

According to John Bell, the concept of judicial independence has been seen as a remedy to a number of problems. First, some courts have been politicised institution, more like an arm of government. The second problem is political influence on judicial decisions, either orders to judges or influence on them or on the proprosecution process. Third problem encountered in many countries is the political influence over the allocation of resources for justice. A fourth problem is political involvement in the selection and career progression of judges. If judges are rewarded or penalised because of their political leanings, this might well influence the performance of their duties. A final problem is the involvement of judges in extra-judicial activities. Some may have political implications, such as chairing an inquiry into a sensitive social issue. ${ }^{8}$ There are a number of specific issues which illustrate these different concerns, such as management (judicial

\footnotetext{
Christopher M. Larkins, “Judicial Independence and Democratization: A Theoritical and Conceptual Analysis”, The American Journal of Comparative Law, Vol 44, No.4, Amarican Society of Comparative Law, p.609-610.

8 John Bell. (2001). Judicial Cultures and Judicial Independence. Cambridge Yearbook of European Legal Studies, 4, 47-60. doi: 10.5235/152888712802761798.
} 
independence as self-government, selection and promotions (judicial independence as freedom from dependence on political authorities), and freedom from outside pressure through their external activities. ${ }^{9}$

Our nation has experienced situations where the judiciary is not in an independent position. In 1964, Law No. 19 of 1964 on the Basic Provisions of Judicial Power was established. In Article 19 stated, "The court is not free from the influence of executive power and the power to make laws. "10 Especially when the Chief Justice is included as one of the ministers in the composition of the cabinet. But in the New Order era, out of Law No. 14 of 1970 on the Basic Provisions of Judicial Power, one of which the article annulled the provisions of Article 19 this. Article 10 paragraph (2) of Law 14/1970 states, "The Supreme Court is the highest state court".11 That is, other power interventions against the judiciary try to be reduced. According to Article 10 Paragraph (1) of Law 14/1970, judicial power is exercised by courts within the General Courts, Religious Courts, Military Courts and Administrative Courts. However, Article 11 of Law 14/1970 actually positioned the judiciary, namely the general courts, religious courts, military court and state administrative court under the authority of the department concerned in terms of its organization, its administration and its finances. Article 11 of Law 14/1970 states, "The judicial bodies mentioned in Article 10 paragraph (1), administrative, administrative, and financial are under the control of each Department concerned."12 While the Supreme Court has its own organization, administration and finance.

That is, the construction of Article 11 of Law 14/1970 when considered, then this article re-establishes judiciaries under the executive, although it is confined to the organizational, administrative and financial aspects only. With this position, the judiciary is no less vulnerable to intervention. This is also the concern of Asnawi Latif from the Fraction of the Union of Daulatul Ummah (F-PDU) in the PAH III Meeting of the MPR 1999 during the process of amendment to the 1945 Constitution which proposed the judicial institutions under one roof, namely MA. Here's his opinion. ${ }^{13}$

"[To] an increase in the authority of the judiciary, as we have proposed yesterday, so that the judiciary, all judicial and judicial institutions, is in one roof, the Supreme Court, both professionally and administratively. During the legs of the judges, one roof in the Supreme Court, one roof in the Department of Justice, the same as the highest and highest institutions of the country, we MPR, but the budget in Setneg. "

This has the potential to affect the independence of the judiciary in general. Therefore, when the momentum of constitutional change (Table 1). When observed, after the amendment of the 1945 Constitution, the assertion that judicial power is an independent power is explicitly stated in the editorial of Article 24 of the 1945 Constitution after the amendment. The phrase "freedom" contains basic principles in the world of justice, including the principles of independence, the principle of impartiality, and the principle of integrity. This means that the institution of the judicial authorities post-1945 amendment is designed to be independent and independent from the influence of any power. This is consistent with the original intent interpretation of Article 24 of the 1945

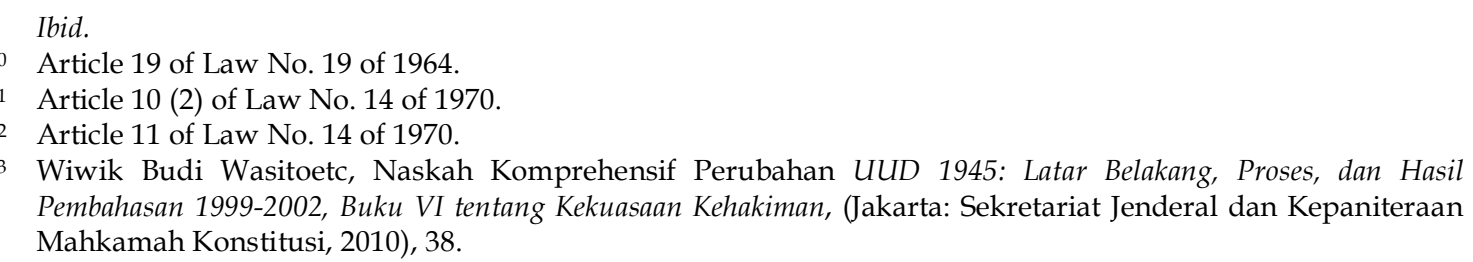


Constitution after the changes that mean the judicial power is an independent power, as stated by one of the members of PAH I BP MPR, Agun G. Sudarsa from Golkar Party Faction when discussing about the judicial power as follows. ${ }^{14}$

"The exercise of judicial power is exercised through a free and impartial judicial process, accessible and quick from investigation, investigation, prosecution, termination to implementation ..."

The existence of independent and independent judiciary actors was also mentioned by Ali Marwan Hanan from the PPP Party who delivered the following. ${ }^{15}$

"... Judicial power is an independent and independent power and independent of the influence of other state power, any interference either directly or indirectly to the judicial authorities is prohibited ...".

Table 1. Comparison Between Article 24 Before and After Constitution Amendment

\begin{tabular}{|c|c|c|c|}
\hline Parag. & $\begin{array}{c}\text { Article } 24 \text { of the } 1945 \text { Constitution } \\
\text { Before Amendment }\end{array}$ & Parag. & $\begin{array}{c}\text { Article } 24 \text { of the } 1945 \text { Constitution After } \\
\text { Amendment }\end{array}$ \\
\hline (1) & $\begin{array}{l}\text { The power of the judiciary is carried } \\
\text { out by a Supreme Court and other } \\
\text { judicial bodies according to the law. }\end{array}$ & (1) & $\begin{array}{l}\text { Judicial power is an independent power to } \\
\text { administer justice in order to uphold law and } \\
\text { justice. }\end{array}$ \\
\hline \multirow[t]{2}{*}{ (2) } & $\begin{array}{l}\text { The structure and powers of the } \\
\text { judicial bodies are regulated by law }\end{array}$ & (2) & $\begin{array}{l}\text { Judicial power is exercised by a Supreme } \\
\text { Court and the lower courts within the general } \\
\text { judiciary, the jurisdiction of the judiciary, the } \\
\text { military court environment, the } \\
\text { administrative court of the state, and by a } \\
\text { Constitutional Court. }\end{array}$ \\
\hline & & (3) & $\begin{array}{l}\text { Other bodies whose functions relate to } \\
\text { judicial power are regulated in law. }\end{array}$ \\
\hline
\end{tabular}

Source: Primary data, 2018.

As a result, in Article 3 of the Judicial Authority Law 2009 is explicitly and clearly stated that the basic character of the judiciary in deciding cases is independent and independent. Even in the provisions of paragraph (3) of the Judicial Power Law of 2009, a person who deliberately intervenes in judicial matters is punishable by a criminal penalty. However, paragraph (2) contains exceptions to this provision as long as it is intended in the 1945 Constitution. This is reasoned because within the Supreme Court, KY serves as an external supervisor based on Article 24B of the 1945 Constitution having authority in the framework of proposing candidates for Supreme Court Justices and in order to preserve the nobility and the dignity of the judge. The provision of Article 24B of the 1945 Constitution seems to indicate that KY interfered in the pattern of recruitment of Supreme Court justices and its supervision, making it appear that the Supreme Court was not free. However, it is not interpreted as KY's interference with the Supreme Court because in principle the Supreme Court has an absolute independence in deciding the case of its authority.

14 Wiwik Budi Wasito. etc. Op.Cit., p. 115.

15 Ibid,118. 
From a theoretical perspective, Montesque once said that judicial power needs to be separated from the legislative and executive powers, because if the legislative power is not separated from the judicial power the judge has no freedom in completing his judicial duties in examining, hearing and deciding cases. The freedom of life and freedom of the subject will be subject to arbitrary control, because the judge will then become a legislator. If the judge is not separated from the executive power, the judge will be easy to commit violence and act arbitrarily. Hence, Montesque's opinion is related to the importance of separation of judicial power separated from the influence of the legislative and executive powers, "... there is no liberty, if the judiciary power is not separated from the legislature and executive. Were it joined with the legislative, the live and the liberty of the subject would be exposed to arbitrary control; for the judge would then be legislator. Were it joined to the executive power, the judge might behave with violence and oppression ".16

On the other hand, the result of the amendment of Article 24 of the 1945 Constitution gave birth to a new state institution, namely the Judicial Commission (hereinafter, KY) and the Constitutional Court (hereinafter referred to as the Constitutional Court). The birth of KY was motivated by negative image of MA at that time which was thick with the scent of judicial corruption and the number of cases arrears, so it came an idea to have an institution authorized to supervise the Supreme Court. ${ }^{17}$

Furthermore, the spirit to make the institution of the perpetrators of judicial power as an independent institution contained in Article 24 of the 1945 Constitution then becomes the spirit in the change of Judicial Power Law. In Article 3 of Law Number 48 Year 2009 regarding Judicial Power, it is stated as follows. ${ }^{18}$

(1) In carrying out its duties and functions, judges and constitutional judges are required to maintain judicial independence.

(2) Any interference in judicial matters by any other party outside the judicial authority is prohibited except in matters referred to in the 1945 Constitution of the State of the Republic of Indonesia.

(3) Any person who knowingly violates the provisions referred to in paragraph (2) shall be liable in accordance with the provisions of laws and regulations.

KY's authority was not spared in the discussion of the trial of PAH I BP MPR. At the 41st Meeting of the PAH I of the People's Consultative Assembly, on June 8, 2000, Agun G. Sudarsa from the Golkar Party Faction conveyed his fraction's views regarding the need for the existence of $\mathrm{KY}$ as follows.

"The Supreme Court established the Judicial Commission to provide recommendations to the MPR on the appointment and dismissal, including the supervision of Supreme Court Justices, whose membership consists of former Supreme Court Justices, legal practitioners, public figures, religious figures and academics"

The same thing was also conveyed by I Dewa Gede Palguna from the PDI-Perjuangan faction who conveyed the necessity of forming a KY to propose a supreme judge.

"... in order to avoid the intervention of the executive power of judges, we propose the establishment of an independent body we call the Judicial Commission at the national and local levels, so that if the former Supreme Court is appointed by the President and the

16 Daniel E. Brannen Jr, Checks and Balances: The Three Barnces of the American Government, Thomson. p,26.

17 Wiwik Budi Wasito.etc. Op.Cit.,

18 Article 3 of Law Number 48 Year 2009 
judges are appointed by the Minister of Justice, proposed for Supreme Court Justices to be appointed by the President, based on the proposal of the National Judicial Commission. And for ordinary judges, meaning outside the Supreme Court, appointed by the President under the Regional Judicial Commission. "

In the end, the third amendment is also agreed in the Plenary Session that the Judicial Commission has the authority as regulated in Article 24B paragraph (1) of the 1945 Constitution which states, "The Judicial Commission is independent which has the authority to propose the appointment of the Supreme Court and has other authority in order to maintain and uphold the honor, the dignity of dignity, and the behavior of judges."

On the other hand, there are new challenges facing the judiciary to maintain its independence. After the constitutional amendment which succeeded in making fundamental changes because of putting the position of religious court, military court, and state administrative court in one roof, namely in the Supreme Court, new problems arise related to the independence of judges. It turns out that a higher court official can also influence the independence of the lower courts. This is based on research results conducted by Indonesia Legal Roundtable (ILR). ${ }^{19}$

Table 2. The Parties that Most Affect the Judges of 2016

\begin{tabular}{lccccc}
\hline \multicolumn{1}{c}{ Party } & Very Often & Often & Quite Often & Infrequently & Never \\
\hline The Local Government & 17.50 & 12.50 & 30.00 & 22.50 & 17.50 \\
Members of parlement & 5.00 & 30.00 & 25.00 & 27.50 & 12.50 \\
Political Party & 10.00 & 27.50 & 25.00 & 25.00 & 12.50 \\
Public Figures & 7.50 & 10.00 & 20.00 & 52.50 & 10.00 \\
Advocat & 20.00 & 32.50 & 25.00 & 17.50 & 5.00 \\
The Mass Organizations & $\mathbf{1 7 . 5 0}$ & 17.50 & 22.50 & 32.50 & 10.00 \\
Entrepreneur & $\mathbf{3 2 . 5 0}$ & 25.00 & 17.50 & 17.50 & 7.50 \\
Higher Court Officials & $\mathbf{2 2 . 5 0}$ & 10.00 & 35.00 & 25.00 & 7.50 \\
\hline
\end{tabular}

Source: Indonesia Legal Roundtable, 2017.

From the Table 2, it can be concluded that there are three parties that influence predominantly on the judicial independency successively, i.e. employers (32.50\%), high court officials $(22.50 \%)$, and community organizations $(17.50 \%)$. Therefore, to maintain the independence of the judiciary requires a genuine effort to establish a transparent and accountable judicial system and reduce direct contact with the litigants. Direct contact with the parties can be reduced by establishing an information technology-based justice system.

\section{Keeping the Rhythm as a Modern and Reliable Judicature}

The Constitutional Court was born in the 3rd amendment in the process of amendment to the 1945 Constitution. The birth of the Constitutional Court is not only to ensure that there is no legal product that contradicts the constitution as the supreme law, but also as a means of strengthening the mechanism of mutual balance and checks and balances

19 Indonesia Legal Roundtable, Indeks Negara Hukum Indonesia, Jakarta, 2017, 40. 
between branch of state power so as to minimize abuse of power, because according to Lord Acton, "power tends to corrupt, absolute power corrupt absolutely,".

Based on Article 24C paragraph (1) of the 1945 Constitution it has been determined that the Constitutional Court has four constitutional authorities and one constitutional obligation. Article 10 Paragraph (1) Sub-Paragraph a through d of Law Number 24 Year 2003 juncto Law Number 8 Year 2011 regarding the Constitutional Court (Law on the Constitutional Court) reinforces the provision by mentioning the four authorities of the Constitutional Court, namely:

a. To examine the law against the 1945 Constitution;

b. To decide upon disputes of authority among state institutions whose authorities are granted by the 1945 Constitution;

c. To break the dissolution of political parties;

d. Disconnecting disputes about election results.

Meanwhile, pursuant to Article 7A and Article 7B Paragraph (1) to Paragraph (5) and Article 24C Paragraph (2) of the 1945 Constitution which is then reaffirmed in Article 10 paragraph (2) of the Constitutional Court Law, the Constitutional Court has an obligation to make the opinion of the People's Legislative Assembly that the President and / or Vice President have committed a violation of law, or a disgraceful act, or do not qualify as President and / or Vice President as referred to in the 1945 Constitution. In addition to having four powers and duties, the Constitutional Court also has a function which is a derivation of the guardian of constitution, the final interpreter of constitution, the guardian of democracy, the protector of citizen's constitutional right, the protector of human rights man (the protector of human rights).

In its development, the Constitutional Court's authority in deciding the dispute over election results was extended not only to the General Elections of DPR, DPD and DPRD members as well as to the Presidential Election, but also to decide disputes over the results of the general elections of regional heads. Under article 236C of the Regional Government Law that the handling of disputes over vote count results of regional head and deputy regional head elections by the Supreme Court shall be transferred to the Constitutional Court at the latest 18 (eighteen) months since the Act is enacted. With the enactment of the article, dispute resolution of local election shall become the authority of the Constitutional Court and local election to be part of the election legal regime.

Furthermore, through Decision Number 97/PUU-XI/2013, the Constitutional Court has canceled and stated that Article 236C of the Regional Government Law does not have a null and void law. Therefore, the Constitutional Court is no longer authorized to adjudicate disputes over the results of regional head elections. According to the Constitutional Court, based on the original intent interpretation, basically the authority of the state institution which is clearly and explicitly described in the 1945 Constitution is limitative so that it is impossible given another authority. Moreover, the other authority is granted by legislation that is hierarchically level under the constitution.

Therefore, from this perspective, the authority of the Constitutional Court is also limitative so that it can not be, local election is not the authority of the Constitutional Court. However, as long as there is no special court to adjudicate the dispute over the results of the Regional Head Elections, the Constitutional Court still has the authority to adjudicate the disputes over the results of the Regional Head Elections. Even the authority of the Constitutional Court in adjudicating disputes over the results of regional head elections in the transitional period before the establishment of a special judicial 
body, currently has been contained in Article 157 paragraph (3) Law No. 10 of 2016 on the Second Amendment to Law No. 1 of 2015 on Determination Government Regulation in Lieu of Law No. 1 of 2014 on the Election of Governors, Regents, and Mayors Become Act.

The Constitutional Court as the judiciary of today is required to always improve itself in order to follow the present trend. Moreover, the Constitutional Court has a vision, "Guarding the uprightness of the Constitution through a modern and reliable Constitutional Court." In this context, the word "modern" has two meanings, namely modern in the sense of the mindset and modern in the technological sense. Modern in the sense of mindset affirms that the current judicial management is professionally managed, accountable and transparent by reflecting the needs of the justice seeker community, so that the best service can be provided. Meanwhile, "modern" in the sense of technology implies the meaning that the management of public administration and judicial administration and service to society must be packed through a technological approach that facilitates access to justice and justices. This is triggered by the development of people's lives that are very fast and dynamic because all the data and information is in the touch of the hand through the gadget. Only armed with search engines on google apps, all references, data, and information we can get. This is certainly a challenge for the court and the secretariat general of the Constitutional Court in realizing the vision of the Constitutional Court.

Since 2008, the Court has conducted long-distance trials through the use of video conferencing (vicon). With the vicon technology, it is possible for the justice seekers to follow the trial of the Constitutional Court without coming to Jakarta. The verification and attendance value of the parties examined through the vicon equipment is the same as the presence in the courtroom in Jakarta. The pattern of long-distance trial conducted by the Court to facilitate access of justice seekers to the judiciary (access to court and justice) considering the location of the Constitutional Court which is only in Jakarta, as the capital of the country.

In order to facilitate the public to the judiciary, now the Court has developed e-Case application, e-BRPK and tracking cases, so that public access to the proceedings in the Constitutional Court can always be followed its development. The public can also monitor the trial in the Constitutional Court through live streaming available on the Court page. Not only that, present trial treatises can be accessed not only in written form but also in the form of audio formats. Of course, this effort is done to increase confidence that the implementation of the trial in the Constitutional Court is open. Currently the Court is very concerned about developing and continually improving ICT-based judicial management system. This is a form of accountability and transparency of the Constitutional Court to the public and efforts in improving excellent service to the public.

On the other hand, for 15 years, many achievements have been made by the Court among others.

1. Maintaining Unqualified Exception (WTP) in a financial manager for 10 (ten) consecutive years. This is a manifestation of the Court's financial reporting that is managed professionally, transparently, accountably, effectively and efficiently.

2. Maintaining the value of Government Institution Performance Accountability System (SAKIP) with a very good predicate.

3. Obtained Bawaslu Awards from Bawaslu RI because the Constitutional Court of the Republic of Indonesia is deemed to have contributed in realizing the elections 
of quality, integrity, dignity and democratic and many achievements, achievements, and other awards can not be mentioned one by one.

Meanwhile, in addition to achievements, to uphold the independence of a credible judicial institution, the Constitutional Court has done a lot of introspection and internal improvement. In order to maintain integrity and professionalism, the constitutional judges and all ranks in the Registrar's Office and the Secretariat General of the Constitutional Court are committed together to achieve the following:

1. Strengthening the supervision system and maintaining the integrity of constitutional justices and all officials and employees in the Court environment.

2. Increase professionalism in the process of handling cases and acceleration of settlement of cases that rely on the quality of the Court's decision to maintain, given the verdict is the judicial crown.

3. To open the widest public access to the case being examined by the Constitutional Court through an ICT-based information system.

These efforts are conducted solely as a manifestation of awareness to realize the constitutionality of Indonesia through the implementation of the constitutional duties of the Constitutional Court towards a better nation and state based on the 1945 Constitution.

Meanwhile, based on data on the Registrar's Office and the Secretariat General of the Constitutional Court, the achievement of the case which became the core business of the Constitutional Court since its establishment in 2003 is as follows. ${ }^{20}$

1. Since its establishment in 2003 until 2017, the Court has registered as many as 2,481 cases consisting of the judicial review of 1,134 cases, the local election as many as 910 cases, Legislative Election Result Dispute as much as 412 cases, and 25 cases of dispute authorities among state institution.

2. Of all cases, 2,432 cases have been terminated with details of 376 cases granted, 1,107 cases rejected, 762 cases unacceptable, 20 cases dropped, 147 cases withdrawn by the Petitioners, 13 cases of follow-up of interlocutory decision and 7 cases declaring the court is not authorized.

3. Based on data recorded by the Court Clerk, cases of judicial review handled by the Constitutional Court from 2003 to 2017 were 1,134 cases and had been decided as many as 1,085 cases with details based on the verdict of 244 cases granted, 379 cases rejected, 325 cases not received, 20 cases of death, 110 cases withdrawn, and against the 7 cases Court declared not authorized. While the remaining 49 cases of judicial review is still being followed by the process of examination in 2018.

4. Throughout 2017, cases of judicial review registered by the Court's Registry of 102 cases and the remaining cases in 2016 amounted to 78 cases, so the total cases to be decided amounted to 180 cases. Of the 180 cases of judicial review, which was successfully terminated until the end of 2017 were 131 cases. Thereby, 49 cases continue to 2018 and by the beginning of 2018 there are 12 registered law enforcement cases, so the total cases in progress until the beginning of this year (Per Feb. 15, 2018) amount to 61 cases.

20 The Annual Report of the Constitutional Court of 2017. 
On the other hand, in its efforts to become a qualified judiciary, the Court has adopted the International Framework for Court Excellent (IFCE) in exercising its authority. Primarily this is done by the Registrar and the General Secretariat as the main supporting the Constitutional Court in performing its duties and constitutional authority. IFCE is an instrument that can be used as a reference for the judiciary in order to realize the judicial institution to be court excellent, so trusted by the public in the search for justice.

To be a court of justice the IFCE instruments according to the instrument must be met is how to internalize the principles of justice. The principles of the judiciary are:21
a. Equality before the law;
b. Fairness;
c. Impartiality;
d. Independence of decision-making;
e. Competence;
f. Integrity;
g. Transparency;
h. Accessibility;
i. Timeliness;
j. Certainty;

Those core values guarantee due process and equal protection of the law to all those who have business before the courts. They also set court culture and provide direction for all judges and staff for a proper functioning court. ${ }^{22}$ Meanwhile, 7 (seven) areas where the application of these values are:

a. Court Management and Leadership;

b. Court Policies;

c. Human, Material, and Financial Resources;

d. Court Proceedings;

e. Clients' Needs and Satisfaction;

f. Affordable and Accessible Court Services;

g. Public Trust and Confidence.

The result of applying the universal principles of justice into these seven trials will result in a quality judiciary, so that public confidence in the judiciary will increase and the prime service of the judiciary to the public can always be given. This is what the MK is currently doing.

\section{Integrity of Constitutional Justices}

Meanwhile, the design of supervision on the Constitutional Court is different from KY. Based on the original intent interpretation of Article 24 of the 1945 Constitution and the Decision of the Constitutional Court Number 005 / PUU-IV / 2006, the Constitutional Court is not the object of supervision of KY. The design of the Constitutional Court's supervision is based on Article 27A of the Constitutional Court Law, namely by establishing the Honorary Council of the Constitutional Court. However, in line with the development of the period, the Constitutional Court has been established as a permanent institution in charge of day to day to maintain the integrity of constitutional

21 International Framework For Court Excellent.(2013). http://www.courtexcellence.com/ /media /Microsites/Files/ICCE/The\%20International\%20Framework\%202E\%202014\%20V3.ashx. [accessed May,2019]

22 Ibid. 
justices. While the Honorary Board is an ad hoc institution in the form of temporary. Although the design between supervision of the Supreme Court and the Constitutional Court is different, in principle, even the institution of judicial authority needs an institution that guards and supervises it.

The reason why KY can not supervise the Constitutional Court is based on Decision Number 005 / PUU-IV / 2006 dated 23 August 2006 and Decision Number 1-2 / PUUXII / 2014, dated 13 February 2014, where the Constitutional Court has decided that the Constitutional Court Judge related to KY which is authorized under Article 24B of the 1945 Constitution. Based on these two decisions, there are at least two reasons why KY is not designed to "supervise" the Constitutional Court, that is, firstly, based on a systematic interpretation of the articles of the Constitution. The position of the Judicial Commission is in Article 24B of the 1945 Constitution, while the Supreme Court is in Article 24A of the 1945 Constitution and the Constitutional Court's position is in Article $24 \mathrm{C}$ of the 1945 Constitution where the article setting one level is under KY. The existence of the positioning arrangements of these articles implies the meaning that $\mathrm{KY}$ is designed to "supervise" judges in the MA and KY environments not designed to "supervise" the Constitutional Court.

Secondly, to avoid conflict of interest (conflict of interest). If KY is authorized to supervise the Constitutional Court, this has the potential to create a conflict of interest when the $\mathrm{KY}$ is a party to a dispute over the authority of a state institution that is the domain of the Constitutional Court's authority. In this condition, the Constitutional Court will be "held hostage" because its supervisory agency is a party to the dispute which must be decided by it. This clearly has the potential to reduce the independence and impartiality of the Constitutional Court as one of the independent judicial authorities based on Article 24 of the 1945 Constitution.

Therefore, the Constitutional Court can not be compelled to be "supervised" by the Judicial Commission, because if so, then what happens is a form of legal smuggling because it is clearly contradictory to the Decision of the Court Number 005 / PUU-IV / 2006 and Decision Number 1-2 / PUU-XII / 2014. If external "oversight" is currently inadequate, there are several steps to be taken: (i) making the Ethics Council or the Honorary Council of Constitutional Justices an independent and independent institution authorized to safeguard the integrity of constitutional justices as well as the Council of Honor Election Organizer (DKPP) for the General Election Commission (KPU) and working day to day; (ii) to amend the 1945 Constitution by placing the position of authority of KY after the authority of MA and MK. That is, the position of KY should be placed in Article 24C after Article 24A which regulates the MA and Article 24B regulating the Constitutional Court. In addition, it should also be stated explicitly in the amendment of Article 24 of the 1945 Constitution that the object of the authority of KY includes also constitutional justices in the Constitutional Court.

In article 24B of the 1945 Constitution it is affirmed that the Judicial Commission has the authority "to uphold and uphold the honor, dignity, and conduct of judges" and not "to supervise". The differences in the words "guarding" and "watching" bring different legal implications. First, the word "guard" contains a prevention perception, while the word "watching" contains perceptions of action; Second, the word "guard" contains "coordinative" perceptions, while the word "watching" contains the perception of "subordination". Therefore, in the context of the judiciary, the amendments to the 1945 Constitution dictate that in Article 24B of the 1945 Constitution the chosen is the word "guard" as a nomenclature option rather than the word "oversee". 
The word "guard" is then interpreted by the legislator to be the word "supervise" as set forth in Article 20 of Law 22 of 2004 on the Judicial Commission, which states, "In exercising the authority referred to in Article 13 letter $b$ the Judicial Commission has the task of supervising the behavior of judges in order to uphold the honor and dignity of the dignity and maintain the behavior of judges ". This article is then canceled by the Constitutional Court because it turns out in practice, the Judicial Commission to oversee the behavior of judges through the judgment of the verdict. This is clearly contradictory to Article 24B of the 1945 Constitution, the principle of res judicata pro veritatehabetur, and the universal principle which states that the court's decision can not be changed except through the verdict of the court itself.

\section{Pattern of Recruitment of Constitutional Justices}

According to Sri Soemantri, one of the ways to obtain a judge with qualified authoritative, honest, fair, and behaving impeccably is to conduct objective recruitment patterns of judges. ${ }^{23}$ There is a close correlation between the pattern of recruitment of constitutional justices with the endeavor to realize quality judiciary. Because if the pattern of recruitment is wrong, then the result is not a competent constitutional judge. Existing current conditions, there is no uniform mechanism between the President, the House of Representatives, and the Supreme Court as the proposing state institution when selecting candidates for constitutional justices. On several occasions, constitutional judges are elected by direct appointment mechanisms. There are also elections conducted by internal teams in private. These two mechanisms are certainly not in line with transparent and participatory principles, so that the objectivity and accountability of the process becomes questionable by the public. ${ }^{24}$ Although there is also a selection conducted by the proposer institution openly, such as the selection process of Moh's successor. Mahfud MD and Harjono conducted by Parliament or election I Dewa GedePalguna by President Jokowi.

Based on Article 19 of the Constitutional Court Law, the nomination of constitutional judges must meet the transparant and participative principles. The word "transparent" implies that the process of recruiting candidates for constitutional justices must be open to the public starting from the announcement of the recruitment process, the recruitment process, and the outcome of the recruitment process. In addition, all processes must be "participatory". That is, in the process required the active involvement of the community to assess the track record of the judges of the constitution. This is important to avoid the election of a constitutional judge from a candidate who has a negative track record. This is also what Moh. Mahfud MD at a public discussion session heard by the Court held by the Registrar and the Secretariat General of the Court after the arrest of one of the judges of the Constitutional Court in early 2017 due to cases of judicial corruption. In addition to being transparent and participatory, the recruitment of constitutional justices must be conducted objectively and accountably.

After the arrest of AM due to judicial corruption case, the President issued Government Regulation in Lieu of Law (Perppu) No. 1 of 2013 in response to public pressure. One of the reasons is to improve the mechanism of judge selection of constitution. In the provisions of Article 18A s.d. Article 18C of the Perppu, the proposing state institution

23 Sri Soemantri. (2014). Hukum Tata Negara Indonesia, Bandung: PT.Remaja Rosdakarya, p. 256

24 Pan Mohamad Faiz. (2017). Mekanisme Seleksi Hakim Konstitusi. Available from https://www.academia.edu/31748428/Mekanisme_Seleksi_Hakim_Konstitusi_Koran_SINDO_aaccessed May,2019]. 
shall nominate a candidate for constitutional judge to the Panel of Experts established by the Judicial Commission. The Panel will conduct a fit and proper test for candidates of constitutional justices. In the end, the Perppu is then approved by the House of Representatives into Law No. 4 of 2014.

The Constitutional Court turned out to completely cancel the Act. According to the Constitutional Court in its legal considerations, the selection of candidates for constitutional justices by the Panel of Experts has reduced, even taken over the constitutional authority granted by the 1945 Constitution to the President, the People's Legislative Assembly and the Supreme Court. Moreover, the panel of experts set out in the Perppu was established by the Judicial Commission. The following quote of the Court's decision in paragraph [3.21], p.110

"Therefore, the formation of Selection Committee or Panel of Experts ever undertaken by the President and the House of Representatives should be continued to be an initiative of each state agency proposer. The formation of a Committee or Panel such as this will be able to reduce the personal interests and the subjectivity of decisions made by the President, Member of the Law Commission of the Parliament, or the Supreme Court. In addition, each of the proposing state agencies must immediately formulate specific internal rules and procedures that remain in line with the selection mechanism of constitutional justices. Without clear rules and procedures, the constitutional judicial selection mechanism will always change every time following the interests and tastes of the proposing agency. "

\section{Several Landmark Decisions: Magnet Toward Public Trust}

Since its inception 15 years ago, the Constitutional Court has played an important and strategic role and position in the reform of law and constitution in our country. In his journey to guard the constitution and democratic process, not infrequently the Court issued a decision that became the landmark decisions because in its legal considerations, the Constitutional Court considered a sense of substantive justice in the midst of society. Although initially the decisions are difficult to accept and considered controversial, but then gradually the public increasingly know the meaning, benefits, and reasons behind the decisions that were dropped. For example, the Constitutional Court canceled Article 50 of the Constitutional Court Law related to the limitation of judicial review authority only to laws established after the first amendment of the 1945 Constitution (vide Decision 066/PUU-II/2004 dated April 12, 2005). Initially this decision had caused controversy in some circles of legal observers, but if only the provisions were not canceled, it has closed the opportunity of justice seekers (justice seeker) to be able to test laws born before the amendment of the 1945 Constitution, such as the Criminal Code, Criminal Procedure Code, Correctional Law, Marriage Law, Narcotics Law, Law Number 02/Pnps/1964, whereas, for example, there are norms in the law that are in fact detrimental to the constitutional rights of citizens and are contradictory to the constitution. Therefore, the Constitutional Court canceled Article 50 of the Constitutional Court Law.

Other milestone rulings that changed the way of punishment, such as decisions that rehabilitated the rights of former and descendants of PKI members (vide Decision Number 011-017/PUU-I/ 2003 dated February 24, 2004), decisions on the permission of independent candidates in local elections (vide Decision Number 5/PUU-V/ 2007 dated July 23, 2007), and the decision on the amendment of the elected candidate counts from the serial number to the majority vote (see Decision Number 22-24/PUU-VI / 2009 dated 
December 23, 2008). The decision to allow the use of identity card or passport as a condition of voting in the Presidential Election due to technical constraints potentially reducing the right of the citizens to vote, the Constitutional Court allows KTP or Passport as a condition to be able to vote (vide Decision Number 102/PUU-VII / 2009 dated July 6, 2009). The verdict limiting the application of the PK only once (vide Decision Number 34/PUU-XI/2013 dated March 6, 2014). Decisions on the implementation of simultaneous General Election of Presidential Election and General Election (vide Decision Number 14/PUU-XI/2013), decisions related to water resources management that restore water resource management obligations to the state, while private sector only obtains residual authority in the exploitation of resources water (vide Decision Number 85/PUU-XI/2013 dated February 18, 2015), a decision involving the appointment of a suspect as an object in pre-trial (vide Decision Number 21/PUUXII/2014 dated 28 April 2015), award (vide Decision Number 97/PUU-XIV/2016), a decision which affirms that the KPK is an independent institution that performs the functions executive in law enforcement so that it may be imposed as the object of the right of inquiry, but related to law enforcement authority cannot be subject to the right of inquiry object (vide Decision 36/PUU-XV/2017).

Decisions which are the legal basis are composed of the opinions of the constitutional justices. These legal opinions form the primary basis for the public's understanding of the current state of law. Writing opinion is also a key element of circuit court's job. Hence, encouraging the writing of better opinions by rewarding those who produce high quality opinion is important. Thus, produce high quality opinion very useful in order to improve the quality of decisions..$^{25}$

\section{Conclusion}

In order to make the Court as a qualified judiciary, not only the institutional aspects and patterns of judge recruitment that need to be considered, but also the decisions. For the verdict is the Crown of the judiciary. Therefore, the achievement and role of the Constitutional Court as a judicial institution in coloring the reform of law and constitution in the country is reflected in its decisions. In deciding a case, the Constitutional Court often applies a progressive legal paradigm that emphasizes the importance of substantive justice rather than procedural justice. This also implies that the judgment of a court is not necessarily bound to be in absolute legalistic formalism, but must also reach one of its main objectives, namely the fulfillment of justice values for the community.

\section{References}

Christopher M. Larkins, "Judicial Independence and Democratization: A Theoritical and Conceptual Analysis", The American Journal of Comparative Law, Vol 44, No.4, Amarican Society of Comparative Law, p.609-610.

Daniel E. Brannen Jr, Checks and Balances: The Three Barnces of the American Government, Thomson.

25 Stephen J. Choi and Mitu Gulati. Choosing the Next Supreme Court Justice: An Empirical Ranking of Judicial Performance (February 17, 2004). UC Berkeley Public Law Research Paper No. 141; Georgetown Public Law Research Paper No. 473281; Georgetown Law and Economics Research Paper No. 473281. Available atSSRN: $\underline{\text { https: / / ssrn.com/abstract }=473281}$ or http://dx.doi.org/10.2139/ssrn.473281 
David S. Law, Judicial Independence, The International Encyclopedia of Political Science, Vol.5, pp.1369-1372, Bertrand Badie, Dirk Berg-Schlosser, Leonardo Morlino, eds., 2011, Washington U. School of Law Working paper No. 10-02-16.

International Framework For Court Excellent. (2013). http://www.courtexcellence.com/ /media/Microsites/Files/ICCE/The\%20International\% 20Framework\%202E\%202014\%20V3.ashx. [accessed May,2019]

John Bell. (2001). Judicial Cultures and Judicial Independence. Cambridge Yearbook of European Legal Studies, 4, 47-60. doi: 10.5235/152888712802761798.

Pan Mohamad Faiz. (2017). Mekanisme Seleksi Hakim Konstitusi. Available from https://www.academia.edu/31748428/Mekanisme_Seleksi_Hakim_Konstitusi_ Koran_SINDO_[accessed May,2019].

Sebastian Pompe. (2012). Runtuhnya Institusi Mahkamah Agung. Jakarta: Lembaga Kajian dan Advokasi untuk Independensi Peradilan.

Sri Soemantri. (2014). Hukum Tata Negara Indonesia, Bandung: PT. Remaja Rosdakarya.

Stephen J. Choi and Mitu Gulati. Choosing the Next Supreme Court Justice: An Empirical Ranking of Judicial Performance (February 17, 2004). UC Berkeley Public Law Research Paper No. 141; Georgetown Public Law Research Paper No. 473281; Georgetown Law and Economics Research Paper No. 473281. Available atSSRN: https://ssrn.com/abstract=473281 or http:// dx.doi.org/10.2139/ssrn.47 3281

The Annual Report of the Indonesian Constitutional Court of 2017.

The Indonesia Legal Roundtable, (2017). Indeks Negara Hukum Indonesia, Jakarta.

Wiwik Budi Wasito et al. (2010). Naskah Komprehensif Perubahan UUD 1945: Latar Belakang, Proses, dan Hasil Pembahasan 1999-2002, Buku VI tentang Kekuasaan Kehakiman, Jakarta: Sekretariat Jenderal dan Kepaniteraan Mahkamah Konstitusi.

Court Decision

Constitutional Court Decision Number 1-2/PUU-XII/ 2014.

Constitutional Court Decision Number 066/PUU-II/ 2004.

Constitutional Court Decision Number 011-017/PUU-I/ 2003.

Constitutional Court Decision Number 5/PUU-V/2007.

Constitutional Court Decision Number 22-24/PUU-VI/ 2009.

Constitutional Court Decision Number 102/PUU-VII/2009.

Constitutional Court Decision Number 34/PUU-XI/2013.

Constitutional Court Decision Number 14/PUU-XI/ 2013.

Constitutional Court Decision Number 85/PUU-XI/2013.

Constitutional Court Decision Number 21/PUU-XII/ 2014.

Constitutional Court Decision Number 97/PUU-XIV/2016.

Constitutional Court Decision Number 36/PUU-XV/2017.

\section{Conflict of Interest Statement:}

The author(s) declares that the research was conducted in the absence of any commercial or financial relationships that could be construed as a potential conflict of interest.

Copyright (C) 2019 HALREV. All rights reserved. 